\title{
BY NIE ZNIWECZYĆ CHRYSTUSOWEGO KRZYŻA (1 KOR 1, 17). ZROZUMIENIE MISTERIUM MĘKI I ŚMIERCI JEZUSA W ŚWIETLE NIEKTÓRYCH ELEMENTÓW CHRYSTIANOLOGII MORALNEJ ŚW. TOMASZA Z AKWINU
}

\section{CONFORMITAS JAKO ZASADA INTERPRETACJI MYŚLI SW. TOMASZA Z AKWINU}

Prezentowana tutaj interpretacja myśli św. Tomasza z Akwinu wchodzi w kontekst zrozumienia tego, co nazywamy "chrystianologią moralną". O tym, że istnieje taka nauka teologiczna jak chrystologia, przekonani są wszyscy. O tym zaś, że istnieje również chrystianologia wie niewielu ${ }^{1}$. Odnowa teologii moralnej,

* Ks. Mirosław Mróz, dr hab. nauk teologicznych w zakresie teologii moralnej, dr filozofii, prof. UMK, kierownik Zakładu Teologii Moralnej i Katolickiej Nauki Społecznej na Wydziale Teologicznym UMK.

${ }^{1}$ Termin „chrystianologia” został wprowadzony do teologii pracą R. Zdziarstka, Chrystianologia św. Pawta, Polskie Towarzystwo Teologiczne, Kraków 1989. O. Augustyn Jankowski OSB we wprowadzeniu do tej pracy tak pisze: „Jest to praca pionierska. Taki jest też termin «chrystianologia», dotąd niestosowany na określenie nielicznych zresztą studiów nad istotą chrześcijanina, nad tą szczególną, nową daną antropologii biblijnej". Stosowanie tego terminu jest na tyle właściwe, iż również moralność chrześcijańską winno się nazywać chrystianologią moralną. Ukazuje bowiem ona w pierwszym rzędzie więzi zarówno ontyczne, jak i moralne, zachodzące między Chrystusem a chrześcijaninem, oparte na dziele Odkupienia i sakramencie chrztu. 
którą postuluje się od czasów dekretu Optatam totius Soboru Watykańskiego II, kieruje się w stronę lepszego powiązana danych teologicznych, zwłaszcza właśnie chrystologii z moralnością chrześcijańską. Jan Paweł II w przełomowej dla teologii moralnej encyklice Veritatis splendor napisze: „Naśladowanie Chrystusa jest pierwszym i najgłębszym fundamentem chrześcijańskiej moralności”2 . A nie można też nie zauważyć, iż to św. Tomasz z Akwinu upominał się o to, aby wszystkie misteria Chrystusa odczytywać jako wzorzec dla ludzkiej drogi łaski i cnoty ${ }^{3}$. Termin conformitas stosowany przez Akwinatę oznacza bycie jak najbardziej podobnym do Chrystusa. Ukazuje, że człowiek zostaje zaproszony do przyjęcia tego samego kształtu, podobnej postaci, podobnego uformowania. "Chrześcijaninem jest ten, kto jest Chrystusów. Chrystusowym zaś jest ktoś nie tylko stąd, że ma wiarę Chrystusową, lecz również stąd, że kierując się Duchem Chrystusa, podejmuje się dokonywania dzieł cnót" ${ }^{\prime 4}$. Dlatego też używany przez Akwinatę termin conformitas, odnoszący się do wzoru formy, jakim jest dla człowieka forma "Chrystus”, zachowuje układ zależności od stopnia doskonałości właściwego właśnie tego wzoru. Tym samym postępowanie Jezusa, Jego słowa, ale również Jego czyny stanowią moralną regułę życia chrześcijańskiego. Tomaszowe conformitas wyznacza miarę, z jaką chrześcijanin włącza się w doświadczenie całkowitego upodobnienia się do Chrystusa. Nie jest ono jedynie zewnętrznym naśladowaniem, ale, jak tego dowodzi wielokrotnie Akwinata w swojej nauce o misteriach życia Chrystusa, wejściem w samą głębię życia i śmierci Jezusa.

Przyglądając się tekstom św. Tomasza z Akwinu można dowiedzieć się, co znaczy „nie niweczyć Chrystusowego krzyża” (1 Kor 1, 17), a tym samym nauczyć się jak umierać razem z Chrystusem. Co to dokładnie znaczy, dowiadujemy się w kontekście przezwyciężania lęku przed śmiercią, który jest autentycznym nośnikiem zrozumienia prawdy o przemianie śmierci w dobro o najwyższej zasługującej próbie.

Trzeba zauważyć, że w nauczaniu Akwinaty istotne jest jego osobiste odniesienie do Chrystusa umęczonego i ukrzyżowanego. Biografowie podają wielokrotnie informacje o szczególnym umiłowaniu modlitwy św. Tomasza i jego kontemplacji krzyża ${ }^{5}$. To ono tutaj staje się ciągle aktualizującym doświadczeniem teologicznego nauczania. Mamy tutaj do czynienia z „wykwalifikowanym świadkiem” takiego doświadczenia bycia w łasce. Doświadczenie to nie jest zarezerwowane dla ludzi o wyjątkowej wrażliwości wewnętrznej,

${ }^{2}$ Jan Paweł II, Encyklika Veritatis splendor, nr 19.

${ }^{3}$ Por. M. Mróz, Człowiek w dynamizmie cnoty. Aktualność aretologii św. Tomasza z Akwi$n u$ w świetle pytania o podstawy moralności chrześcijańskiej, WSD, Torun 2001, s. 491-513.

${ }^{4}$ S. Th., II-II, q. 124, a. 5.

${ }^{5}$ Por. J. A. Weisheipl OP, Tomasz z Akwinu. Życie, myśl i dzieło, W drodze, Poznań 1985, s. 234-239. 
ale także może zostać rozszerzone, a nawet powinno, na każdego człowieka usprawiedliwionego mocą śmierci Chrystusa.

Św. Tomasz z Akwinu wskazuje, że nie wystarcza jakieś bierne umieranie razem $z$ Chrystusem, które byłoby umieraniem dla siebie, trzeba umierać dla innych. Jego przesłanie ukazuje taką naukę o krzyżu, która nie ma rozdziału pomiędzy Chrystusem a chrześcijaninem: jest określeniem faktu, że forma śmierci Chrystusa określa formę życia i śmierci każdego chrześcijanina. Ta zasada przekracza jednak wymiar prostej postawy etycznej, jest już moralnością chrystyczną. Postawą tego, kto należy do Chrystusa. Chrystianologia moralna budowana na bazie teologii Akwinaty może zaznaczyć z naciskiem, że rezygnacja z własnej doskonałości, a przyjęcie doskonałości samego Chrystusa, jest odpowiedzialnością nie jedynie za siebie samego, lecz za innych. Tak jak Chrystus jest pośrednikiem między Bogiem a ludźmi, tak i człowiek przyjmuje na siebie właśnie to pośrednictwo: nie tylko wobec ludzi za Chrystusa, ale także wobec Chrystusa za ludzi. Bez tego związania i bez jednoczesnego jego doświadczenia postępowanie i całe życie chrześcijanina jest niezrozumiałe i nie do przyjęcia. Istniejąca tutaj normatywność polega zaś właśnie na potraktowaniu swojego życia jako powołania i upodobnienia się do Chrystusa.

\section{WAŻNOŚĆ KONTEKSTU POWSTANIA PIERWSZEGO LISTU DO KORYNTIAN DLA ZROZUMIENIA ISTOTY NAUKI O KRZYŻU}

Pierwszy List do Koryntian, a zatem także owe słowa: By nie zniweczyć Chrystusowego krzyża (1 Kor 1, 17), szczególnie nas tutaj interesujące, został napisany w Efezie podczas trzeciej podróży misyjnej (lata 53-58) i dłuższego pobytu Apostoła w tym mieście. Adresatami listu są zaś chrześcijanie w Koryncie. Paweł przebywał w Koryncie podczas swojej drugiej podróży misyjnej, głosząc przez osiemnaście miesięcy Ewangelię Chrystusową, co każe przypuszczać, że list został zredagowany około roku 56-57. Bezpośrednim powodem napisania listu była być może wizyta „ludzi Chloe” $(1,11)$ oraz specjalne poselstwo z Koryntu (por. 16, 17), informujące św. Pawła o niezbyt pomyślnej sytuacji wśród pierwotnej gminy w Koryncie, żyjącej w środowisku greckim. Powodem rozłamu wewnątrz gminy, istniejących tam niepokojów i kłótni był błąd w zrozumieniu nauki chrześcijańskiej, który niejako intuicyjnie dostrzegł św. Paweł. W swoim liście stara się ów błąd Koryntian naprawić, przekazując dane o istocie orędzia chrześcijańskiego. Koryntianie bowiem, tworząc rywalizujące ze sobą wewnątrz wspólnoty koła, zaczęli głosić i postępować w taki sposób, jak gdyby Ewangelia była wymysłem ludzkim, powiedzielibyśmy nawet, zwykłym systemem filozoficznym, mądrością ludzką. Św. Paweł stara się od pierwszych słów swego listu wytłumaczyć, iż mądrość Boża nie oznacza czegoś teoretycznego, zespołu nowych, do tej pory nieusłyszanych jeszcze wiadomości i prawd, ale jest 
działaniem Bożym poprzez krzyż Chrystusa, który jako jedyny stanowi dobrą nowinę, Ewangelię o zbawieniu.

Formuły treściowe nie stanowią jeszcze istoty rzeczy. Taki bowiem aspekt można by nazwać jeszcze ciągle swoistą retoryką i wiedzą o krzyżu, która jest swoiście pojętą "materią wiary”, ale jeszcze nie życia in forma crucis. Takie ujęcie pozbawia krzyż jego istoty i skuteczności. Jest to, co prawda, już owoc przepowiadania, gdyż człowiek sam nie osiągnąłby „wiedzy” o krzyżu, ale z mądrością prawdziwą mamy do czynienia dopiero wtedy, gdy przejdzie się ów pułap ludzkiej miary i możliwości słów i argumentacji, a dzięki łasce stanie się on osobistym wydarzeniem i mocą.

Stąd św. Tomasz będzie mógł powiedzieć w swoim komentarzu I ad Corinthios do 1, 17: Ut non evacuetur crux Christi (By nie zniweczyć Chrystusowego krzyża):

Zasadniczą kwestią w doktrynie wiary chrześcijańskiej jest zbawienie dokonane przez krzyż Chrystusa (Principale autem in doctrina fidei Christianae est salus per crucem Christi facta). Stąd w rozdziale drugim mówi: Postanowiłem bowiem, będąc wśród was, nie znać niczego więcej, jak tylko Jezusa Chrystusa, $i$ to ukrzyżowanego. Tutaj zatem zasadniczy zaczyn [złożony] w nauczanej mądrości słów, tkwi w tym, co jest w nich samych (quantum in se est), aby nie zniweczyć krzyża Chrystusowego. Stąd nauczać [jedynie czystej] mądrości słów nie jest sposobem odpowiednim dla wiary chrześcijańskiej (Ergo docere in sapientia verbi non est modus conveniens fidei christianae). I to dlatego powiada aby nie zniweczyć krzyża Chrystusowego, który jest, nie w słowach mądrości przepowiadanych tak, aby się [komuś] przypodobać, [a co byłoby równoznaczne z] usunięciem wiary [tkwiącej] w mocy krzyża Chrystusa (tollatur fides de virtute crucis Christi). Gal [5], 11: Przecież wtedy ustałoby zgorszenie krzyża. Ps 137, 7: Kiedy oni mówili: «Burzcie, burzcie aż do fundamentów» ${ }^{6}$.

Nie chodzi tutaj, aby głosząc moc zbawczą krzyża, unicestwić człowieka z jego myśli, ogołocić go z jego sądów, ale o to, aby to nie była zwykła inteligencja ani nawet praktyczna umiejętność argumentacji o krzyżu, ale uczestnictwo w samym zamyśle Boga, który w swojej Mądrości przewidział krzyż swojego Syna. Bóg bowiem prowadząc ludzi do zbawienia, wziął pod uwagę nawet grzech człowieka. Nie niszczy On nawet tych wysiłków ludzkich, które zmierzają do złego celu, ale włącza je do swojego planu, sprawiając, że stają się „błogosławioną winą" człowieka.

${ }^{6}$ Św. Tomasz z Akwinu, Komentarz do I Listu do Koryntian (I ad Corinthios), cap. I, lect. III (1, 17b), nr 45 (tłum. własne). 
Istnieje więc baza mądrościowa w człowieku, ma ona swoją wartość, chociaż o krzyżu nic nie wie, a człowiek o „materii” krzyża dowiaduje się z przesłania wiary. Ten materialny aspekt wiary może zostać potraktowany jednak jedynie jako swoista prawda intelektualna, jako odkrycie tworzące pewien chrześcijański system czy też światopoglądową orientację. Można nawet o nią się bić i mając do niej osobiste przekonanie stawać w jej obronie. Mamy tutaj do czynienia z ograniczonością przyrodzonego spojrzenia na rzeczywistość prawd objawionych, które nie jest w stanie oprócz konsekwencji poznawczych dostrzec, pójść jeszcze dalej i zanurzyć się w poznane prawdy całoosobowym oddaniem się im, gdyż są drogą ku Bogu żywemu i własnemu zbawieniu.

Św. Tomasz powie bardzo wyraźnie, iż nie wszyscy wierzący w Boga posiadają wiarę, która może być nazwana wiarą żywą, tzn. zbliżającą wierzącego człowieka do życia wiecznego. Może to być wiara martwa, a więc taka, która jest jedynie ograniczona do postrzegania prawd Bożych z pozycji zewnętrznego obserwatora, prawd, które nie dostarczają duszy momentu zdolnego przemienić się i wierząc, iść ku Bogu Żywemu.

Wiara domaga się dwojga: pierwsze, podania człowiekowi prawd wiary, by mógł wierzyć w coś wyraźnie określonego; drugie, uznania za prawdę przez wierzącego (człowieka) tego, co mu się (do wierzenia) podaje ${ }^{7}$.

Św. Tomasz, powołując się na wypowiedź Jk 2, 19: „lecz także i złe duchy wierzą i drżą", powie, że wiarę, w sensie uznawania prawdy objawionej w kontekście poznawania materii, ma nawet szatan. Oczywiście taka wiara nie jest darem łaski, koegzystuje ona z przewrotnością szatanów.

wiara, którą mają szatani, nie jest darem łaski; raczej zmusza ich do uwierzenia przyrodzona bystrość rozumu. Samo nawet to nie podoba się szatanom, że znaki potwierdzające wiarę są tak oczywiste, że zmuszają ich do uwierzenia; dlatego też przez to, że wierzą, wcale nie zmniejsza się ich złośliwość8.

Także człowiek może być w podobnym stanie ducha. To, co piętnuje św. Paweł w swoim Pierwszym Liście do Koryntian nie jest odrzuceniem mądrości jako takiej, ale wskazaniem, iż nauka o krzyżu nie może zatrzymać się na poziomie treści samej mowy, nie można pozbawić krzyża jego istoty i skuteczności. Nie jest on bowiem dany, aby dyskutować o nim, lecz po to, aby go przeżyć. Nie należy więc wskazywać na przykład, że to kazanie o krzyżu było lepsze, ten kapłan rekolekcje wielkopostne dotyczące krzyża wygłosił lepiej i elokwentniej,

\footnotetext{
${ }^{7}$ S. Th., II-II, q. 6, a. 1c.

${ }^{8}$ Tamże, q. 5, a. 2, ad 2 i 3.
} 
ale ważniejsze byłoby zastanowić się, czy została ukazana w nich „mądrość Boża", mądrość łaski. Jeżeli bowiem mamy do czynienia jedynie z elokwencją ludzką, to spotykamy się z martwotą Ewangelii; słowa mogą bowiem być nieudolne, ale w rzeczywistości chodzi o fakt i skuteczność łaski, o zanurzenie w misterium, a nie zatrzymanie się na słowach, jak na szybie. Chodzi zatem o spojrzenie dalej w przestrzeń, którą dopiero wtedy mogą opisywać elokwencja i mądrość ludzka.

Dlatego św. Paweł, ganiąc frakcje w gminie korynckiej: stronnictwo Apollosa, „męża uczonego i biegłego w Piśmie” (18, 24), stronnictwo Kefasa, chrześcijan palestyńskich przybyłych do Koryntu wskutek prześladowań przez Sanhedryn czy też przez Heroda Agrypę I, stronnictwo powołujące się na samego Pawła, powstałe z tych, którzy odwoływali się do czasu jego nauczania w Koryncie, czy też tzw. stronnictwo Chrystusa', opierające się według nich jedynie na autorytecie Ewangelii, bez względu na to, kto ją głosił Koryntianom, chce wskazać na fakt, że nauka krzyża nie jest mądrością pojmowaną na sposób ludzki i kryteriami mądrości horyzontalnej, ale ocenić ją trzeba w kontekście łaski, kiedy to nie tylko informuje, ale także oczyszcza ludzkie serce. Św. Tomasz dużą wagę przywiązuje do faktu, iż jednym ze skutków wiary jest czystość serca. Stąd może też powiedzieć, że mądrość jest darem łaski i to ona sprawia: „poprawność sądu o sprawach Bożych, albo według prawideł Bożych o innych sprawach, w wyniku swoistego pokrewieństwa czy jedności z rzeczami Bożymi"10.

Taka mądrość nie tylko poznaje, ale także zmienia samo życie człowieka: „mądrość jako dar jest wyższego rzędu niż mądrość jako mądrość jako cnota umysłowa [wypracowana własnym wysiłkiem ludzkim], ponieważ dosięga Boga z większą bliskością, mianowicie poprzez swoistą jedność duszy z Nim, dowodzi to, że nie tylko zarządza w dziedzinie kontemplacji, lecz także postępowania praktycznego"11. Dla św. Pawła i św. Tomasza jest jasne, że mądrość Boża to nie tylko teoria, ale i praktyka: sapientia, secundum quod est donum, non solum est speculativa, sed etiam practica ${ }^{12}$. Znaczy to, że nauka o Chrystusowym krzyżu nie odnosi się jedynie do poprawności myślenia ani nie może być zaszeregowana do przestrzeni, w której mamy do czynienia z umiłowaniem prawdy dla niej samej, ale wiąże się z możliwością rozszerzenia także, a może nawet przede wszystkim kierowania sobą według jej prawideł. Dzięki temu darowi mądrość Dobrej Nowiny o krzyżu staje się skuteczna i przemieniająca. Dlatego

${ }^{9}$ Według niektórych egzegetów, mamy tutaj do czynienia z nieświadomym zniekształceniem imienia Kryspus, zwierzchnika synagogi w Koryncie, który będąc wybitną postacią w młodym kościele korynckim, skupił przy sobie wielu zwolenników.

${ }^{10}$ S. Th., II-II, q. 45 , a. 4 .

11 Tamże, a. 3, ad 1.

12 Tamże, a. 3c. 
jest nad wyraz praktyczna. Nie ma bardziej skutecznej i praktycznej nauki ani też bardziej przydatnej sprawności niż mądrość wypływająca z krzyża. Stąd tak bardzo różni się ona zarówno od mądrości greckiej, gdzie dotyczy ona jedynie kwestii racjonalnego wyjaśnienia rzeczywistości, jak i od mądrości żydowskiej, gdzie prawo znajdowało się nie tyle na pozycji usprawiedliwienia, ile raczej było przyczyną oskarżenia człowieka przed Bogiem. Jedyny środek do zbawienia Bóg dał ludzkości w mocy krzyża. Kryteria filozoficzne, żadne też sądy logiczne ani mądrość słowa nie mają znaczenia, dlatego że ani nie przynoszą człowiekowi zasługi (meritum), ani nie dają oswobodzenia ku autentycznej wolności dzieci Bożych.

Negatywny stosunek św. Pawła do mądrości ludzkiej nie oznacza negatywnego stosunku do ludzkiego rozumu. W komentarzu Tomaszowym widać to bardzo wyraźnie. Trudno jest człowiekowi żyć praeter rationem, „wbrew”, „przeciw”, „obok”, „mimo” czy „poza” rozumem. Życie poza rozumem okazuje się zgubne. To, co zostaje zakwestionowane w tym przypadku, to zgoda na wewnętrzną sprzeczność z zasadami i prawdami rozumu ujawniającą się w przypadku pychy i zarozumiałości ludzkich spekulacji i słów. Akwinata z całą mocą opowiada się za możliwością traktowania Bożych rzeczywistości jako przedmiot dociekań, niemniej punktuje te momenty, w których można zbłądzić. Oto co mówi na ten temat w swoim Komentarzu do De Trinitate Boecjusza:

Można tu jednak trojako zbłądzić. Po pierwsze, przez zarozumiałość, gdy mianowicie ktoś tak roztrząsa Boże tajemnice, jakby je doskonale pojmował. [...] Po drugie, może tu zbłądzić przez to, że w sprawach związanych z wiarą będzie się dawać pierwszeństwo rozumowi przed wiarą. Dzieje się tak, gdy ktoś chce wierzyć tylko w to, co można odkryć rozumem, podczas gdy powinno być na odwrót. [...] Po trzecie, porywając się na takie dociekanie Bożych rzeczywistości, które przekracza własne zdolności ${ }^{13}$.

Nic dziwnego, iż rozum i poznanie prawdy, także te wynikające z wiary materialnej, można wykorzystywać instrumentalnie po to, aby osiągnąć doraźne cele czy wręcz czerpać z nich korzyści. Stąd wiedza ta zamiast stać się mocą człowieka, tracąc status służebny, zaczyna hołdować procesowi pogłębienia nieprawości ludzkiej.

Pod koniec XX wieku, kard. Angelo Scola podał przyczyny współczesnego sekularyzmu, twierdząc tak: „samo jądro historyczno-teoretyczne teorii sekularyzacji polega właśnie na [...] immanentnej interpretacji całościowego sensu dziejów"14. A znaczy to, z perspektywy wiary, że zagubiono centralność

${ }^{13}$ Św. Tomasz z Akwinu, Super Boetium De Trinitate, q. 2, a. 1c, w: O poznawaniu Boga, wyd. łac.-pol., Wydawnictwo „M”, Kraków 2005, s. 111-112.

${ }^{14}$ A. Scola, Wydarzenie Jezusa Chrystusa dzisiaj, „Communio", XVII (1997), nr 98 (2), s. 11. 
wydarzenia Jezusa, gdy bowiem nawet odwoływano się do kategorii wydarzenia w teologii dzisiejszej, wszystko to opracowywano bez doświadczenia tegoż wydarzenia ${ }^{15}$. Można by powiedzieć, że współcześnie mamy także do czynienia z błędem piętnowanym przez św. Pawła w Pierwszym Liście do Koryntian: błądem metodologicznym pysznego rozumu. Metodą może być tylko jeden podstawowy moment mówiący o tym, iż istnieje aktualność i teraźniejszość wydarzenia krzyża. Nie jest on tylko symbolem, czy też prezentacją takich brutalnych czasów, które w historii posiadają swoje powtórzenia. Krzyż nie jest jedynie ostrzeżeniem przed okrucieństwem, nienawiścią i wzajemną wrogością. Jeżeli nie uzna się teraźniejszości krzyża i wydarzenia zbawczego, jakim jest interwencja Boga przepojona miłością właśnie w śmierci Syna, to niemożliwa i niezrozumiała stanie się treść świadectwa tej formy, jaką jest krzyż. Krzyż przyjmie na nowo jedynie stwierdzenia czysto intelektualne i zostanie zredukowany do samych tylko technik psychopedagogicznych.

Współczesna mądrość rozumu ludzkiego ponownie idzie linią świata pogańskiego, który nie poznał Boga. Mądrość krzyża, zrozumienie jego sensu i wartości, czyli dogłębne wniknięcie i uczestnictwo życia każdego, kto chce być w zamiarach Bożych, dokonuje się na poziomie przyjęcia daru i praktycznego odczytania własnej niemocy, a także poszukiwania światła i siły, które mogłyby stanowić tarczę przed śmiercią i osądem Boga. Rozwiązanie zostało dane: "spotkanie", „pozostawienie wszystkiego", co wiąże własny horyzont spojrzenia w kategoriach przedmiotu, i pójście za Tym, który zbawia.

\section{ODNALEZIENIE DROGI: SPOTKANIE Z CHRYSTUSEM, KTÓRY UMIERA NA KRZYŻU „DZISIAJ” I TO „DLA MNIE”}

Pierwszym krokiem, niejako zewnętrznym, decydującym o „moim” zbawieniu jest kryterium doświadczenia osobistego spotkania z Chrystusem. Chodzi tu o tego Chrystusa, którego na podstawie doświadczenia rozpoznajemy jako przyjaciela - wzór zrealizowanego człowieczeństwa: „«Znaleźliśmy Mesjasza» - to znaczy: Chrystusa" (J 1, 41). Św. Tomasz tak komentuje ten fragment Ewangelii Janowej:

Dlatego mówi: Znaleźliśmy [słowa wypowiedziane przez Andrzeja], przez co też potwierdził, że szukał Go długo i pełen pragnienia, Prz 3, 13: Szczęśliwy człowiek, który znalazł mądrość. Mesjasza, po hebrajsku, po grecku zaś Chrystusa, czyli Namaszczonego po łacinie (Unctus): jest bowiem w sposób szczególny namaszczony niewidzialnym olejem, tj. Duchem Świętym. I dlatego znamiennie tym imieniem wskazuje na Niego. Stąd też słowa w Ps

${ }^{15}$ Por. tamże, s. 12. 
45 (44), 8: Namaścit cię Pan olejkiem radości przed towarzyszami twymi, tj. przed wszystkimi świętymi, jako, że wszyscy święci tym olejem byli namaszczeni. On jednak namaszczony został w sposób jedyny i w sposób jedyny jest świętym. Dlatego właśnie według Chryzostoma, Ewangelista nie używa samego słowa «Chrystus», lecz dodaje zaimek ${ }^{16}$.

Tak jak ongiś Andrzej Apostoł powiedział do swojego brata Szymona. Ten wymiar osobistego spotkania stanowi oryginalność chrześcijańskiej egzystencji: jest to podstawowe doświadczenie potrafiące zmienić życie ${ }^{17}$.

Takie wydarzenie opisane zostało przez św. Jana (J 1, 37-39): „Dwaj uczniowie usłyszeli, jak mówił i poszli za Jezusem. Jezus zaś odwróciwszy się i ujrzawszy, że oni idą za Nim, rzekł do nich: «Czego szukacie?» Oni powiedzieli do Niego: «Rabbi! - to znaczy Nauczycielu - gdzie mieszkasz?» Odpowiedział im: «Chodźcie, a zobaczycie». Poszli więc i zobaczyli, gdzie mieszka, i tego dnia pozostali u Niego. Było to około godziny dziesiątej". Tomasz tak interpretuje to wydarzenie:

W znaczeniu mistycznym zaś mówi: „przyjdźcie i zobaczcie, że zamieszkanie Boga, czy to w chwale czy w łasce, nie może być poznane inaczej jak przez doświadczenie i nie może być wyrażone słowami. Ap 2, 17: Na kamyku imię nowe itd. [Kto ma uszy, niechaj posłyszy, co mówi Duch do Kościołów. Zwycięzcy dam manny ukrytej i dam mu biały kamyk, a na kamyku wypisane imię nowe, którego nikt nie zna oprócz tego, kto [je] otrzymuje]. Dlatego więc mówi Chrystus: Przyjdźcie i zobaczcie. Przyjdźcie - wierząc i działając - i zobaczcie - doświadczając i pojmując ${ }^{18}$.

Pozostanie u Jezusa nie ograniczyło się tylko do jednego dnia, w którym uczniowie doświadczyli, że ten, którego spotkali, był Mesjaszem, czyli nie ograniczyło się do dnia ich powołania, ale rozciągnęło się na całe ich życie. Trzeba niejako zapisać sobie to doświadczenie, jedno jedyne w naszym życiu i zaszyć w kieszeni marynarki, aby chwytać sobie to miejsce w chwilach zwątpienia, i trwać. Doświadczenie takiego spotkania jest tak ważne, że zapamiętuje się nawet dokładnie nie tylko datę, ale wręcz godzinę i wszelkie okoliczności. W życiu każdego człowieka zapamiętane zostają pewne wydarzenia, decydujące o własnej egzystencji, które tak mocno zostają wryte w pamięć, że przekazują mądrość o życiu, odkrywają istotę życia. W takim spotkaniu to sam Bóg nawiedza duszę człowieka. Jest to właściwe dla Osoby Boskiej: „być dana i być Darem"19.

\footnotetext{
${ }^{16}$ Św. Tomasz z Akwinu, Komentarz do Ewangelii Jana, rozdz. I, wykł. 15 [301].

${ }^{17}$ Por. A. Scola, dz. cyt., s. 12-13.

${ }^{18}$ Św. Tomasz z Akwinu, Komentarz do Ewangelii Jana, rozdz. I, wykł. 15 [292].

${ }^{19}$ Por. S. Th., I, q. 38, a. 1.
} 
Św. Tomasz powie:

Bóg nie jest daleko od nas, nie jest poza nami, lecz jest w nas [...]. Dlatego doświadczenie dobroci Boga jest nazywane «kosztowaniem» (gustatio). [...] Doświadczenie to przynosi dwojaki skutek: pierwszy to pewność umysłu, drugi - bezpieczeństwo afektywności ${ }^{20}$.

Widać tutaj wyraźnie, iż doświadczalnej rzeczywistości Bożej Tomasz przypisuje także niewątpliwy ładunek emocjonalny, chociaż nie odwraca się od porządku, który obejmuje zarówno rozum i wolę. Istnieje więc bez wątpienia poznanie spraw Bożych, którego nie można nabyć drogą prostego studium. Istnieje doświadczenie, które nie jest czystym aktem teoretycznym, jak w przypadku, gdy coś się rozumie i uważa za rzeczywiste, ale zachowuje się, jakby mnie to nic nie obchodziło. Przeciwnie, $\mathrm{w}$ takim doświadczeniu to coś bardzo mnie obchodzi, obchodzi całą moją osobę, obchodzi, bo dotyka mojego życia. W tym doświadczeniu nie można tego się nie trzymać, bo to coś mnie przenika. Dzięki temu doświadczeniu wszystko stapia się w jeden akt: poznanie i wola i uczucie, a z tego rodzi się także i czyn. Jest to łaska doświadczenia.

Przez dar łaski uświęcającej rozumne stworzenie jest doskonalone do tego, aby nie tylko swobodnie używać stworzonego daru, ale by także radować się sama Osobą Boską. I dlatego niewidzialne posłanie dokonuje się przez dar łaski uświęcającej, a jednak zostaje dana sama Osoba Boska ${ }^{21}$.

Takie doświadczenie $\mathrm{w}$ niczym nie narusza indywidualności człowieka. Przeciwnie ta indywidualność nadal trwa, lecz taska doświadczonego spotkania sprawia, iż człowiek rozumie także siebie coraz bardziej, a może nawet przede wszystkim do siebie samego dociera najbardziej, dlatego że wzbogacony zostaje obecnością prawdy. Doświadczenie takie jest najbardziej własne, wyciska swoją pieczęć na zrozumieniu siebie jako całości.

Doświadczenie, o którym tutaj mowa, jest także pewnego typu doświadczeniem człowieka jako człowieka, „doświadczeniem istotowo ludzkim”. K. Wojtyła pisze w swojej książce Osoba i czyn: pisze w ten sposób:

Kiedy [...] mowa o doświadczeniu człowieka, to chodzi nade wszystko o fakt, że człowiek styka się, czyli nawiązuje kontakt poznawczy z sobą samym.[...] Zachodzą w nim momenty bardziej wyraziste, a oprócz tego, cały ciąg momentów mniej wyrazistych, które jednak razem składają się na

${ }^{20}$ Św. Tomasz z Akwinu, Komentarz do Psalmów, Ps 33, nr 9 (za: J.-P. Torrell OP, Św. Tomasz z Akwinu. Mistrz duchowy, W drodze, Poznań-Warszawa 2003, s. 136).

${ }^{21}$ S. Th., I, q. 43, a. 3, ad 1. 
swoisty całokształt doświadczenia tego człowieka, którym jestem ja sam. [...] $\mathrm{W}$ najściślejszej łączności z tym kontaktem przebiega proces zrozumienia, który także ma swoje momenty i swój ciąg22.

Człowiek w poznaniu Chrystusa poznaje siebie. Doświadczenie i spotkanie z Wydarzeniem, jakim jest Jezus (dzisiaj obecnym dla mnie na sposób eucharystyczny), daje możliwość pokazania Jego drogi i faktu, że jest ona także moją.

Pojawia się też odpowiedź na pytanie o związek tego, o czym tutaj mowa, z nauką o krzyżu. Rzecz jest bowiem w swojej prostocie zaskakująca. Od czasu, kiedy przez łaskę Chrystus i dusza nie są już sobie obcy, przeznaczeniem bowiem duszy jest właśnie takie spotkanie, nie może ona oderwać się od prawdy o sobie i pozostaje z nią na zawsze. Odkąd Chrystus w łasce doświadczenia stał się jej „kosztowaniem”, to nie może ona inaczej jak tylko przeżyć całe Jego życie. Musi dojrzewać razem z Chrystusem, a nade wszystko przejść z Nim Jego drogę ku śmierci. Każdy człowiek musi cierpieć i umrzeć, ale jeśli jest chrześcijaninem, tzn. należącym do Chrystusa (,jest Chrystusów”), taki był jego wybór, to jego brama do życia na wieki wiedzie przez śmierć z Chrystusem, i to także $\mathrm{w}$ takiej formie, iż trzeba umierać nie dla siebie, ale „dla" świata.

Spotkanie z krzyżem, albo raczej z Ukrzyżowanym, ma taką moc, że chrześcijanin staje się alter Christi, na siebie przyjmuje Jego czyny. „Chodź i zobacz". Chrześcijanin widzi, że "godzina" Chrystusa jest także i Jego godziną. Niejako mówi: zobacz, że mam godzinę dla Ciebie, którą jest moja śmierć, a robię to dla Ciebie. Jednakże zgoda i pójście na śmierć z Chrystusem jest dla człowieka pewną drogą. Na niej musi najpierw umrzeć „stary człowiek”, czyli śmierć dla grzechu, a także usunięcie lęku o siebie, czyli zatracenie życia na własną rękę i przyjęcie mocy płynącej z życia Bożego.

To, że zagubiona została centralność tego wydarzenia Jezusa, spotykanego w łasce doświadczenia wiary, jawi się jako istotna przyczyna zatracenia zrozumienia w ogóle przesłania Ewangelii jako Dobrej Nowiny.

\section{4. "DLA MNIE ŻYĆ, TO UMRZEĆ" Z CHRYSTUSEM DLA GRZECHU}

Bóg zbawia przez śmierć i zmartwychwstanie Chrystusa. Samo imię Jezus, Jeshua, oznacza: „Bóg, który zbawia”. To rdzeń chrześcijaństwa. Zbawić oznacza wyzwolić się od ostatecznego, radykalnego zła. Takim złem jest odejście człowieka od Boga. „To jest życie wieczne: aby znali Ciebie, jedynego prawdziwego Boga, oraz tego, którego posłałeś, Jezusa Chrystusa" (J, 17, 3).

\footnotetext{
${ }^{22}$ K. Wojtyła, Osoba i czyn, Polskie Towarzystwo Teologiczne, Kraków 1985, s. 5-6.
} 
Świat nie potrafi wyzwolić człowieka od zła grzechu i śmierci i sprawić, aby żył on na wieki.

Św. Tomasz mówi za św. Augustynem: „Na naszą nędzę nie było lepszego lekarstwa niż męka Chrystusa" ${ }^{23}$. Jaka to nędza, którą św. Tomasz będzie nazywał culpa (wina, grzech) i miseria (Chrystus wyzwolił nas, dał nam wolność: libertas a culpa [wolność od grzechu], i libertas a miseria [wolność od nędzy bytu i egzystencji człowieka]?

Istnieje w człowieku „wołanie” o wolność od grzechu. Współczesny jednak człowiek rozwija w sobie poczucie własnej bezgrzeszności. Wielu spostrzega siebie jako ludzi wprawdzie ułomnych, ale fundamentalnie sprawiedliwych. Człowiek oddala od siebie myśl, że wskutek grzeszności, tzn. oddalenia od Boga, cały jego organizm duchowy dotknięty jest ciężką chorobą. Człowiek ponosi skutki pierwszego grzechu najpierw przez fakt zerwania relacji z Bogiem, co posiada swoje uzewnętrznienie w krajobrazie duszy ludzkiej. Człowiek został zraniony, jak mówi Tomasz, w całym organizmie władz swojej duszy (vulnera naturae ex peccato consequentia) ${ }^{24}$ : rana nieznajomości (vulnus ignorantiae) pozbawia rozum właściwego porządku w stosunku do prawdy; rana złośliwości (vulnus malitiae) pozbawia wolę właściwego stosunku do dobra; rana słabości (vulnus infrimitatis), rana siły gniewliwej, z której grzech usunął należny porządek w stosunku do trudu; rana pożądliwości (vulnus concupiscentiae), rana siły pożądliwej, z której grzech zniszczył porządek w stosunku do przyjemności miarkowanej przez rozum. Poprzez grzech człowiek pogłębia swoje oddalenie od Boga i drugich oraz swoje własne ograniczenia realizacji dobra.

Tak więc upodabniamy się do Jego [Chrystusa] śmierci, w miarę jak umieramy dla grzechu, gdyż On umarł dla życia śmiertelnego, w którym był podobny do grzechu, chociaż grzechu w Nim nie było. Zatem wszyscy, którzy zostaliśmy ochrzczeni, umarliśmy dla grzechu ${ }^{25}$.

Człowiek współczesny często nie zdaje sobie sprawy, że jego szamotanie się to nic innego, jak pragnienie uwolnienia się ze swojej grzeszności, czyli ze swego oddalenia od Boga. Tylko zbliżenie się do Niego w Jezusie Chrystusie, który posiada najważniejsze lekarstwo, jakim jest drzewo krzyża, przynosi pokój. Już Pius XII zwrócił uwagę na zanik poczucia grzechu, twierdząc, że właśnie to jest najważniejszym problemem człowieka, najstraszniejsza rzeczą, która jego spotyka w naszych czasach. Być wolnym od grzechu i od zamętu, który istnieje w duszy człowieka. Usunąć owego „starego człowieka” i przyodziać nową szatę.

${ }^{23}$ S. Th., III, q. 46, a. 3, sed contra.

${ }^{24}$ S. Th., I-II, q. 85 , a. 3.

${ }^{25}$ Św. Tomasz z Akwinu, Komentarz do Listu do Rzymian, rozdz. 6, wykł. 1, nr 473, (tłum. pol. s. 96-97). 
Kiedy „człowiek stary”, chociaż jeszcze młody wiekiem, rozgląda się, w jaki sposób uwolnić się od swojej grzeszności, swojej nędzy wewnętrznego "zamętu" (perturbatio), a więc jest wewnętrznie zdezorientowany, czyli nie ma kierunku, żyje w wewnętrznym zamieszaniu i nie może sobie wtedy poradzić ze swoją i innych codziennością, tęskni za lepszym światem, i nie tylko w jakimś kawałku, ale chce lepszego świata całego, zupełnie innego, może popaść (i niestety często się to zdarza) w nałóg narkotyku. Branie narkotyków jest rezultatem nieradzenia sobie z własnym zamętem, szukaniem dróg wyjścia i przemiany na własną rękę. Wtedy taki człowiek zasklepia się w czystej technice. Narkotyk jest rezultatem zwątpienia w możliwość wyzwolenia się z własnego chaosu. Technicznym narzędziem, jakim jest wyprodukowany narkotyk, chce znaleźć inny, odnowiony świat, swój własny i drugich ${ }^{26}$.

Oczywiście chrześcijanin wie, że „nowy człowiek” to przede wszystkim Chrystus, to w Nim i przez Niego człowiek ma umierać ciągle na nowo "staremu człowiekowi" w zjednoczeniu z Chrystusem.

Wiemy, że mamy umierać, ale jak to uczynić? Aby zrozumieć drogę, na której człowiek umiera dla grzechu, trzeba najpierw dokładnie zrozumieć, co się stało w grzechu pierworodnym. Nauka św. Tomasza jest tutaj bardzo dokładna.

Bóg obdarzył człowieka w momencie stworzenia dobrem polegającym na tym, że jak długo jego umysł będzie podległy, niższe władze jego duszy będą podległe rozumowemu umysłowi, a ciało będzie podległe duszy. Ponieważ jednak umysł człowieka odstąpił od uległości Bogu przez grzech, w rezultacie również jego niższe władze nie podlegają całkowicie rozumowi. $\mathrm{Z}$ tego wynikł taki bunt żądz (appetitus) cielesnych przeciw rozumowi, że także ciało nie w zupełności podlega duszy. $Z$ tego zaś wynika śmierć i inne niedomagania cielesne. Życie bowiem i zdrowie ciała zależy od uległości duszy, jako coś co może być doskonalone dzięki temu, co je doskonali. Stąd odwrotnie, śmierć, choroby i wszelkie niedomagania cielesne są wynikiem braku podległości ciała duszy. Z tego wynika, że jak bunt dążeń cielesnych przeciw duszy, tak również śmierć i wszystkie podległości cielesne są karą za grzech pierwszych rodziców ${ }^{27}$.

Pierwszy człowiek zgrzeszył głównie dążeniem do podobieństwa z Bogiem w zakresie znajomości dobra i zła, co jemu podsuwał wąż. Chodziło mu o to, by człowiek siłami własnej natury decydował, które czyny mają być dobre i złe dla niego, oraz także, by sam z siebie naprzód wiedział, co do-

\footnotetext{
${ }^{26}$ Por. J. Ratzinger, Czas przemian w Europie. Miejsce Kościoła $i$ świata, Wydawnictwo „M", Kraków 2001, s. 14-16.

${ }^{27}$ S. Th., II-II, q. 164 , a. 1c.
} 
brego lub złego może go spotkać. Drugorzędnie zaś zgrzeszył zdążaniem do podobieństwa z Bogiem co do samodzielnej mocy działania, a chodziło mu o to, by osiągnął szczęście działaniem siłami własnej natury. [...] zdążali [tak człowiek, jak i diabeł] do dorównania Bogu, tym mianowicie, że chcieli polegać na sobie z odrzuceniem porządku naznaczonego przez prawo Boże ${ }^{28}$.

Stan człowieka jest stanem szukania szczęścia własną mocą, chociaż Bóg już uprzednio ofiarował człowiekowi łaskę i życie wieczne. Niemniej pycha człowieka rzekła „,ja sam”, „bez Boga”. Ten stan człowieka wyraża obraz śmierci fizycznej. Jest ona właśnie obrazem śmierci duchowej, odwróceniem się od Boga Życia i Miłości.

Otóż karą wyznaczoną za pierwszy grzech i równą mu było odebranie daru Bożego, utrzymującego harmonię w naturze ludzkiej i jej integralność (fuit subtractio divini deneficii quo rectitudo et integritas humnae naturae). Niedomaganiami zaś wynikłymi z odebrania tego daru są śmierć i inne kary obecnego życia ${ }^{29}$.

Rozwiązany został węzeł pierwotnej niewinności, owa pierwotna "harmonia”, gdzie dominowała integracji elementów duszy i ciała oraz pokój, zarówno wewnątrz, jak i na zewnątrz człowieka. Teraz zaś trzeba go tworzyć na nowo.

Martin Buber, przedstawiciel tzw. filozofii dialogu, który prezentuje inny, co prawda, system myślenia niż Akwiata (św. Tomasz z Akwinu relacjonuje prawdę o człowieku w języku filozofii istnienia, Martin Buber zaś nie idzie droga bytu, ale przez osoby oraz spotkanie osób: „ja” i „ty”: oba jednak ujęcia ujmują podstawowy wymiar bytowania człowieka, jakim jest kategoria doświadczenia odnosząca człowieka do Boga), w swoim studium na temat Obrazów dobra $i z ł a^{30}$, potwierdza opisany przez św. Tomasza stan dezintegracji duszy człowieka historycznego:

W pierwszym stadium rzeczywistości życia biblijnym obrazom zła odpowiada zamysł człowieka, by zamiast rzeczywiście, pozornie przezwyciężyć chaotyczny stan duszy, stan pozbawionego kierunku falowania namiętności, chęć wyrywania się z niego w punkcie, gdzie można zrobić wyłom, zamiast zdobyć przez zjednoczenie sił kierunek, który można zdobyć tylko w taki sposób ${ }^{31}$.

${ }^{28}$ Tamże, q. 163, a. 2c.

${ }^{29}$ Tamże, II-II, q. 164 , a. 1 , ad 4.

${ }^{30}$ M. Buber, Obrazy dobra $i$ zła, w: Ja $i$ Ty. Wybór pism filozoficznych, IW Pax, Warszawa 1992, s. 169-206.

${ }^{31}$ Tamże, s. 204. 
Kierunek pozorny, zjednoczenie sił nie wychodzi, człowiek nie ma siły i mocy zapanować nad swoją duszą w taki sposób, aby z chaosu doprowadzić do harmonii, nie ma sposobu i takiej mocy, aby moc duszy dała ciału upragnioną przez nie niezniszczalność.

Dla prawdziwej decyzji, podejmowanej całą duszą, jest tylko jeden kierunek: bez względu na to, odnośnie do czego podejmuje każdorazowo decyzje, w rzeczywistości bytu wszystkie one są jedynie wariacjami jednej decyzji i podejmowane są wciąż na nowo w jednym kierunku. [...] ten jedyny kierunek rozumie się jako kierunek $\mathrm{ku} \mathrm{Bogu}^{32}$.

Zgadza się to z myśleniem Akwinaty, który twierdził, że to rozum jako najwyższa władza jest władzą kierowniczą. Nadaje kierunek ku dobru, które w człowieku poznaje. Tym dobrem najwyższym jest Bóg. Słowa M. Bubera są tego dowodem:

Zła nie można popełnić całą duszą, całą duszą można czynić tylko dobro. Dobro czyni się wtedy, gdy poryw duszy, wychodzący od jej najwyższych sił, obejmuje wszystkie siły i wrzuca je w oczyszczający i przemieniający ogień: potęgę decyzji. Zło jest brakiem kierunku i wynikającym stąd chwytaniem, łapaniem, uwodzeniem, zmuszaniem, wykorzystywaniem, naginaniem, dręczeniem, niszczeniem tego, co się nadarza. Dobro jest kierunkiem i tym, co się w tym kierunku czyni; to zaś, co się czyni, czyni się całą duszą, tak iż do czynu włącza się wszelka siła i namiętność, którą można by czynić zło. W tym kontekście należy przypomnieć sobie ową talmudyczną interpretację biblijnej wypowiedzi Boga o «złym» wyobrażeniu lub popędzie, którego siłę trzeba włączyć w miłość do Boga, jeśli chce się Mu prawdziwie służyććn

Umrzeć ma w nas stary człowiek. Co to oznacza? Wyniszczenie tego, co należy do duszy? Żadną miarą. Wszystko, co jest, jest dobre. To, co należy do ciała, i to, co należy do duszy, także popęd seksualny, namiętności, wszystko jest dobre. Trzeba jednak przeprowadzić je przez „ogień oczyszczający”: decyzję, która prowadzi do umierania grzechu w ciele człowieka, a trzeba tego dokonać razem z Chrystusem, który umiera w ciele za "moje” grzechy.

Jest to jednak nie tyle decyzja człowieka, ile uprzedzająca decyzja Boga, który nie odwraca swojego oblicza od człowieka, który odszedł i odwrócił się od Niego. Dlatego, właśnie człowiek podejmie swoją decyzję, tzn. włączy się do decyzji samego Boga, dzięki czemu jest to decyzja oczyszczająca. Sama decyzja człowieka nie miałaby tej mocy. Bóg, rekonstruując obraz człowieka na wzór swego Syna, człowiek został bowiem stworzony na obraz i Jego podobieństwo,

\footnotetext{
32 Tamże, s. 205.

${ }^{33}$ Tamże, s. 200.
} 
nie rekonstruuje tej czy innej części, ale idzie tutaj o całość. Jeśli człowiek ma stać się na powrót miły Bogu, musi dojść do „przeistoczenia”, „przemienienia”, "metamorfozy” (por. Rz 12, 2; 2 Kor 3, 18), przemiany postaci "starego" w „nowego” człowieka.

Decyzja pojęta przez Boga: posłanie swojego Syna dla naszego zbawienia, jest tą jedyną Dobrą Nowiną, którą człowiek mógł usłyszeć i być nią z jednej strony zdziwiony, ale także uszczęśliwiony. Decyzja Boga jest decyzją ukazania Chrystusa jako ukrzyżowanego, a przez to danie i postawienie człowieka w takiej sytuacji, iż może on przyjąć od Chrystusa moc umierania dla siebie i moc brania Jego krzyża. To zamysł samego Boga Ojca, to okazanie w obrazie Ukrzyżowanego koncepcji na życie dla Boga. Wywołuje to okrzyk człowieka: „Do mnie przyszła Ewangelia: Dobra Nowina! Dziękuję Boże!”.

Człowiek uznaje tu, że sam nie da rady, nie ma takiej mocy, sam nie może się zbawić. Jest to też wiadomość umożliwiająca spotkanie w Duchu Świętym obecnym w Kościele. Każdy człowiek wszystkich czasów ma możliwość osobistego dotknięcia wydarzenia krzyża: działania męki, śmierci i zmartwychwstania. Światło oświecające człowieka zostało zapalone w nowym posłuszeństwie tej wyjątkowej decyzji Boga. Ostatecznie człowieka zbawia moc Boga wtedy, gdy postawi się on po stronie Ukrzyżowanego.

Chrystusowa "godzina" rozpoczyna się w Ogrodzie Oliwnym, w Getsemani. Od początku Jezus żyje świadomością celu swego przyjścia, jakim było zanurzenie się w śmierci. Bóg, przeprowadzając swojego Syna przez śmierć, czyli przez tę barierę, która determinuje życie człowieka, a także trzyma go w niewoli lęku, udostępnia perspektywę jakości nowego życia, jakim jest życie zmartwychwstałe. Przyjęcie męki, konania, umierania i śmierci Jezusa jeżeli odbije się swoim podobieństwem i moca, także $\mathrm{w}$ naszym ciele, to stanowi środek i narzędzie do objawienia się mocy zmartwychwstania. „Jeżeli bowiem przez śmierć, podobną do Jego śmierci, zostaliśmy z Nim złączeni w jedno, to tak samo będziemy z Nim złączeni w jedno przez podobne zmartwychwstanie" $(\mathrm{Rz} 6$, 5). Chodzi w pierwszym rzędzie o zjednoczenie z Chrystusem, który świadomie przyjął kierunek ku śmierci. Mamy tu ukazany kierunek wzrastania ku śmierci, a co także w życiu człowieka jest rzeczą naglącą, jeżeli człowiek spojrzy na siebie realnie, gdyż śmierć jest normalną, chociaż docierającą po grzechu pierworodnym, konsekwencją życia ludzkiego. Ukierunkowanie na śmierć w sensie fizycznym następuje już w chwili narodzin, pod względem duchowym (obejmuje on całego człowieka, jego duszę i ciało) w momencie chrztu. To ten sakrament dokonuje bowiem prawdziwego i trwałego zrośnięcia z Chrystusem w jego umieraniu ${ }^{34}$.

${ }^{34}$ Por. Z. Kiernikowski, Moc umierania duchowa cechq pasterza, „Pastores”, 1 (2005), s. $18-27$. 
Jezus wchodzi w mękę i śmierć jako wolny, dający się pojmać z gotowością na skrępowanie. Dlatego pierwszym krokiem jest wolne przyzwolenie na „skrępowanie". Człowiek wchodzi w komunię z Jezusem, a dzieje się to głównie po to, aby to On w nas się stawał, $\mathrm{w}$ momencie, gdy rozpocznie swoje własne skrępowanie. Człowiek chce nosić na sobie Jezusowe chwalebne skrępowanie. Męka Jezusa rozpoczyna się od sceny w Ogrójcu. „Tamci zaś rzucili się na Niego i pochwycili Go" (por. Mk 14, 42-52). Jezus zostaje skrępowany i opuszczony przez wszystkich. W zwyciężaniu siebie, ze starym człowiekiem, w swoim własnym umieraniu dla grzechu człowiek zostaje sam z Jezusem. Tylko Jezus może dać moc w przetrwaniu mojemu wewnętrznemu skrępowaniu i decyzji poskromienia grzechu ${ }^{35}$. Tradycyjnie nazwa się to ascezą. Grecki termin askesis wywodzi się od czasownika askéo, oznacza wysiłek, ćwiczenie się. Tu człowiek ćwiczy się w byciu związanym dla grzechu, jak Chrystus.

To już jest potęga decyzji - kontynuowanie pójścia z Chrystusem drogą Jego męki i śmierci jako ognia oczyszczającego. Decyzja ta, określona tutaj jako "ogień", oczyszcza nie tylko tę, czy inną wadę, nie zatrzymuje się nad tym, czy innym grzechem, ale decyduje o całości człowieka, nadaje nowy, chrystyczny kierunek.

Obrazem, który dobrze - jak sądzę - ukazuje fakt ukrzyżowania swoich żądz, jest scena z Odysei Homera, a której bohaterem jest Odyseusz przepływający obok wyspy syren. Scena ta była ulubionym tematem $\mathrm{w}$ tekstach takich pisarzy i Ojców Kościoła jak Tertulian, Orygenes, Hieronim, Ambroży itp. ${ }^{36}$ Syreny są tutaj symbolem świata pokus, które jako ponadludzkie są silniejsze od człowieka. Podobnie szatan jest istotą, która przekracza inteligencję i moc ludzką. Człowiek jest arumim, „nagi”, jak nadzy byli pierwsi rodzice. Wąż jest arum - najbardziej przebiegły. Znaczenie ma tutaj gra podobnych słów w języku hebrajskim. Przebiegły wąż staje naprzeciw słabości człowieka. Wąż-kusiciel posiada inteligencję upadłego anioła przekraczającą naszą wiedzę i potrafi zwieść i wykorzystać nasze ograniczenia ${ }^{37}$.

Homerowskie rozwiązanie jest następujące (Odyseusz dowiaduje się o nim od nimfy Kirke, a to oznacza, że przygotowuje się do drogi, zaciąga wiadomości o drodze): zatkać uszy współtowarzyszom, a samemu każe się przywiązać do masztu i nakazuje towarzyszom, aby go jeszcze mocniej przywiązali, gdy będzie się wyrywał i błagał o uwolnienie w chwili kuszenia.

${ }^{35}$ Por. tenże, Dobra Nowina dla grzesznika, Bernardinum, Pelplin 2004, s. 121-124.

${ }^{36}$ Posługiwanie się obrazami mitów greckich w myśli chrześcijańskiej analizował H. Rahner w Griechische Mythen in christlicher Deutung, por. H. Rahner, Die Versuchung der Sirenen, "Communio" (wyd. niemieckie) 29 (2000), nr 1, s. 63-75; tutaj za: K. Grzywocz, Nie dopuść, abyśmy ulegli pokusie, w: Pokusa, „Zeszyty Formacji Duchowej”, nr 18, Wydawnictwo Salwator, Kraków 2002, s. 62-65.

${ }^{37}$ Por. K. Wons, Mechanizmy pokusy, w: Pokusa, s. 21. 
Życie i śmierć rozstrzygają się w chrześcijańskim Misterium przy maszcie morskiego statku płynącego ku niebu. Tym masztem jest Krzyż, a chrześcijanin jest z wolności przywiązanym do Krzyża zwycięzcą ${ }^{38}$.

Umieranie dla grzechu nie oznacza wyniszczenia natury, łaska zasadza się na naturze, porządkuje ją i wywyższa. Związuje węzłem miłosierdzia i łaski do Chrystusowego Krzyża.

\section{PRZEMIENIENIE LĘKU PRZED ŚMIERCIĄ: USTABILIZOWANIE CZKOWIEKA W TAJEMNICACH ŻYCIA CHRYSTUSA}

Człowiek przeżywa lęk przed śmiercią; to podstawowa trwoga człowieka. Śmierć jest czymś niewyobrażalnym, jest czymś, czego właściwie człowiek nie doświadcza, niemniej jednak czuje przed nią trwogę. "Człowiek jej nie czuje, gdy umrze, a nie może jej czuć, gdy jej nie ma" ${ }^{\prime 39}$ - to zdanie - jakże przepojone nutą doświadczalnej wiedzy o fenomenie śmierci, które mogłoby też sugerować przejście obok niej, tak jakby jej wcale nie było - jest autorstwa św. Tomasza, podobnie jak również i to, że jedną z kar nałożonych na człowieka po pierwszym grzechu jest: „ciągła pamięć przyszłej śmierci”40. W śmierci istnieje pewna ambiwalencja: z jednej strony nie ma nic pewniejszego niż śmierć i łącząca się z nią prawda o przemijaniu, z drugiej zaś człowiek może jej doświadczyć jedynie we właściwym znaczeniu jedynie jako śmierci bliźniego. Już jednak i to wystarcza. Martin Heidegger w swojej znanej książce Sein und Zeit dowodzi, że lęk przed śmiercią stanowi stałą atmosferę, w której jawi się życie ludzkie. Praktycznie wszystko, co człowiek czyni, jest spowodowane pragnieniem ucieczki przed tą świadomością, która to jawi się jako podstawowa troska człowieka.

Jestestwo umiera faktycznie, jak długo egzystuje, jednakże zrazu i zwykle w sposób / upadania. Faktyczne egzystowanie nie jest bowiem tylko w sposób ogólny i obojętny rzuconą możnością-bycia-w-świecie, lecz zawsze już zanurzone w „świecie” zatroskania. W tym upadającym byciu przy... daje o sobie znać ucieczka od nieswojości, co teraz znaczy: przed najbardziej własnym byciem ku śmierci. Egzystencja, faktyczność, upadanie charakteryzują bycie ku kresowi i są w związku z tym konstytutywne dla egzystencjalnego pojęcia śmierci. Z racji swej ontologicznej możliwości umieranie opiera się na trosce ${ }^{41}$.

${ }^{38}$ H. Rahner, dz. cyt., s. 75-75 (cyt. za: K. Grzywocz).

${ }^{39}$ S. Th., II-II, q. 164, a. 1, ob. 7.

${ }^{40}$ S. Th., II-II, q. 164, a. 2c.

${ }^{41}$ M. Heidegger, Bycie $i$ czas, tłum. pol. B. Baran, Wydawnictwo Naukowe PWN, Warszawa 1994, s. 254. 
Tenże sam M. Heidegger wyczuwa, iż dramat troski człowieka (Sorge) potrzeba przemienić w troskliwość (Fürsorge), aby stać się mocnym. Groźba śmierci kryje się jednak ciągle w ludzkiej niepewności jutra, niemożliwości zaspokojenia do końca potrzeb zarówno materialnych, jak i duchowych, w społecznej bezdomności, egoistycznej egzystencji i wzajemnej separacji. Człowiek czuje, iż trzeba wyzwolić się ze śmiertelnej niemocy troski, nie wie jednak do końca jak. Może jedynie przez pewien czas uczynić swoją troskę znośną, a czyniąc tak, tym bardziej radykalizuje swoją własną trwogę.

Tylko jeden jest w stanie uwolnić od troski: Jezus Chrystus. Tylko On pouczył i dał moc przemiany ludzkiego lęku w przyjęciu tego dramatu ludzkiego serca: dokonuje się to nie poprzez ucieczkę od śmierci, co obserwuje się współcześnie, np. w przyjmowaniu i akceptacji narkotyków jako iluzorycznej drogi wyzwolenia z niemocy, ale w przyjęciu własnej śmierci. Do takiego kroku człowiek jest zdolny jedynie razem z Chrystusem, w Chrystusie i przez Chrystusa, przyjmując Dobrą Nowinę o Jego krzyżu.

Tak bowiem jak mogę siebie, moje grzechy obmyć we krwi baranka, a one ponad śnieg wybieleją, tak także moją troskę, lęk i trwogę przed śmiercią mogę przemienić w dobro zasługujące, w rzeczywistość w służbie zbawienia.

Jaki jest stosunek Chrystusa do rzeczywistości śmierci, widać na przykładzie Jego zachowania się, kiedy stoi przy grobie swojego zmarłego przyjaciela Łazarza. Szczególnie wiele mówiące są słowa odnotowane przez Ewangelistę Jana $(11,33)$ : ęnebrimčsato to pneümati. Najczęściej są one tłumaczone jako „wzruszył się", chociaż ich sens dosłowny jest inny, znaczy po prostu: „zagniewał się w duchu". Tymi słowami św. Jan pragnie wyrazić, poprzez taką właśnie reakcję Jezusa, ów Boski gniew na niegodziwość śmierci, którą trzyma świat i człowieka w okowach ciągłej troski i smutku. Przed śmiercią nie obronił się nawet przyjaciel Jezusa, śmierć dotknęła i jego, tak jak dotyka każdego człowieka $^{42}$. Św. Augustyn tak komentuje tę scenę w swoim kazaniu:

[Nie wzruszył się i] nie płakał wówczas nad umarłym, którego wskrzesił, ale z powodu śmierci, którą człowiek sprowadził na siebie przez grzech. Gdyby bowiem nie było grzechu, śmierć by niewątpliwie nie przyszła. Przyszła śmierć nawet na ciało, a poprzedziła ją śmierć duszy ${ }^{43}$.

Jakie rozwiązanie kwestii śmierci, niepokoju o siebie, o swoje życie daje Jezus? Jak sprawia, że ona nie jest w stanie przemóc człowieka i to nawet w samym momencie śmierci? Jezus daje jedyne i ostateczne rozwiązanie. Rozwiązaniem jest umrzeć z Chrystusem. Chrystus umiera po to, abym ja mógł

\footnotetext{
${ }^{42}$ Por. R. Gauardini, Wolność - taska - los, Znak, Kraków 1995, s. 231.

${ }^{43}$ Św. Augustyn, Kazanie 173, 2, za: J. Salij, Spotkanie śmierci greckiej z biblijna, „Literatura na świecie", 8-9 (169-170), 1985, s. 433.
} 
umrzeć z Nim, ale umierając z Nim, żyć na wieki w domu troskliwości Boga Ojca. Jego śmierć nie była śmiercią dla siebie samego, ale śmiercią dla mnie, abym to ja wiedział i potrafił przezwyciężyć moją troskę, a przede wszystkim to zatroskanie, jakie przeszywa moje serce: jak żyć prawdziwie i to na wieki?

Doświadczenie śmierci z Chrystusem przemienia się w możliwość i skuteczność zmartwychwstania z Chrystusem.

Św. Tomasz z Akwinu stale powraca do faktu przyczynowości sprawczej tkwiącej we wszystkich tajemnicach życia Chrystusa. Znamienne jednak, iż moc zbawcza płynie z misterium paschalnego.

Potrzeba [...], abyśmy najpierw zostali upodobnieni do Chrystusa cierpiącego i umierającego, następnie byśmy doszli do uczestnictwa w podobieństwie [jego] zmartwychwstania ${ }^{44}$.

Trzeba podkreślić, iż akcentowane podobieństwo do Chrystusa w Jego męce nigdy nie jest oderwane od zmartwychwstania. Czynić tak jedynie można dla lepszego uchwycenia samego jądra logiki krzyża i hermeneutyki śmierci. Akwinata nie traci z oczu całego misterium paschalnego, gdzie zmartwychwstanie Chrystusa jawi się jako centralna tajemnica z życia Chrystusa. To jedynie bowiem dzięki zmartwychwstaniu i uwiecznieniu w Jego chwalebnym człowieczeństwie każdego z Jego ziemskich uczynków, może On działać swoją mocą przebóstwiającą. Chrystus zmartwychwstały zachowuje wieczną, przemienioną „pamięć” tych wszystkich tajemnic swego ziemskiego życia, które były Jego udziałem. Uwielbione człowieczeństwo Zmartwychwstałego zachowuje nadal aktualnie to, co odnosi się do innych tajemnic Jego życia. Mówiąc precyzyjnie językiem św. Tomasza, przyczynowość sprawcza minionych tajemnic (z życia Chrystusa), w tym także tajemnicy męki i śmierci, wypływa z faktu zmartwychwstania, a konkretnie z mocy człowieczeństwa, które dzięki bóstwu Chrystusa doświadczyło powrotu do życia. O tym fakcie nie należy nigdy zapominać.

Zadośćuczynienie Chrystusa osiąga w nas swój skutek, o ile stajemy się z Nim złączeni jak członki z głową [...]. Członki zaś muszą upodobnić się do głowy (membra autem oportet capiti conformari). I dlatego, tak samo jak Chrystus posiadał najpierw łaskę $\mathrm{w}$ duszy wraz z podatnością na cierpienia ciała, a przez mękę doszedł do chwały nieśmiertelności; tak samo i my, którzy jesteśmy Jego członkami, dzięki Jego męce jesteśmy uwolnieni od stanu zasługiwania na jakąkolwiek karę, ale w taki sposób, że najpierw przyjmujemy w naszej duszy Ducha przybrania za synów (Rz 8, 15), dzięki któremu zostaje nam przyznane dziedzictwo nieśmiertelnej chwały. Aż do tej pory mamy ciało śmiertelne i podatne na cierpienie. Potem zaś, upodob-

${ }^{44}$ S. Th., III, q. 56, a. 1 , ad 1. 
nieni do Chrystusa przez Jego cierpienia i śmierć (Flp 3, 10), zostaniemy doprowadzeni do nieśmiertelnej chwały, zgodnie z tym mówi Apostoł (Rz 8, 17): jeśli jesteśmy dziećmi Bożymi, to i dziedzicami, dziedzicami Boga, a współdziedzicami Chrystusa, jeśli przynajmniej z Nim cierpimy, aby mieć udział w jego chwale ${ }^{45}$.

Przyniesione przez Chrystusa rozwiązanie, wraz z wynikającym stąd ustabilizowaniem napięcia ludzkiej trwogi i lęku, nie oznacza jednak uprzedniego czy samoczynnego wyeliminowania dramatu konkretnego człowieka. Dar Chrystusa zostaje ofiarowany wolności człowieka, który współdziałając z łaską dokonuje - o dziwo - nie złagodzenia, ale radykalizacji swojej pozycji, poznaje bowiem ją lepiej, dając jednak możliwość wejścia w służbę i troskę samego Jezusa i jego dążeń ${ }^{46}$.

\section{ZROZUMIENIE WAŻNOŚCI UMIERANIA "DLA"}

Największa odpowiedzialność: niemożliwość pozostawienia drugiego w obliczu śmierci. Śmierci za innego, jest to śmierć bez pożądania, jak śmierć Maksymiliana Kolbe w obozie koncentracyjnym Auschwitz. Nie ma żadnych innych darów, darowuje się swoje życie. Śmierć czyni dar - darem czystym, bez domieszki jakiegokolwiek własnego interesu, usuwa siebie, a przemienia niejako własne ,ja”, które ofiarowuje siebie „dla” w czysty dar.

Gdyby nie miłość Jezusa na krzyżu, objawienie tej miłości na krzyżu, człowiek nie wiedziałby, jaki jest związek miłości i śmierci.

Ludzie walczący o eutanazję nie widzą tego związku, nie rozumieją i nie są w stanie przyjąć tego rozwiązania. Jest to dar, tak jak miłość jest darem. Do śmierci człowiek przygotowuje się całym życiem, nie jednak tak, aby było to umieranie z życia na własną rękę, lecz przyjęcie życia z ręki Boga. Śmierć, która jest złem, może zostać przemieniona w dobro przez miłość.

Św. Tomasz z Akwinu tak powie, powołując się na św. Augustyna:

„Jak źli źle używają rzeczy nie tylko złych, ale nawet dobrych, tak sprawiedliwi dobrze używają nie tylko tego, co dobre, ale nawet tego, co złe. Stąd pochodzi, że źli ludzie robią zły użytek z prawa, chociaż prawo jest dobre, a dobrzy dobrze umierają, chociaż śmierć jest złem". Tak więc śmierć staje się zasługująca dla świętych dlatego, że robią z niej dobry użytek ${ }^{47}$.

\footnotetext{
${ }^{45}$ S. Th., III, q. 49, a. 3, ad 3.

${ }^{46}$ Por. V. Battaglia, Mieć udziat w dążeniach Chrystusa, w: Bóg bogaty w mitosierdzie (Kolekcja Communio, nr 15), Pallottinum, Poznań 2003, s. 316-330.

${ }^{47}$ S. Th., II-II, q. 164, a. 1, ad. 6.
} 
Co to oznacza „umrzeć dobrze” i zrobić ze śmierci „dobry użytek zasługujący"? Już wiemy, że to oznacza umrzeć z Chrystusem.

Dla Edyty Stein to jest nie tylko teoria, ale i praktyka. Wie o tym już wcześniej, zanim stanie się „dla”, w miłości: „Scientia crucis - zdobywa się tylko wtedy, gdy się samemu do głębi doświadcza krzyża. Od początku byłam o tym przeświadczona i powiedziałam z całego serca: Ave Crux, Spes unica"48.

Widzimy tu śmierć jako ostatni akord upodobnienia się do Chrystusa, upodobnienia się do Jego sposobu bycia miłością: jest to miłość, która jest niczym innym jak tylko czystym darem, gdzie nawet sama osoba zanika z pola widzenia, ona cała w śmierci staje się niejako nieobecna, ona jest obecnością siebie. Cały być miłością. Gdy dla przykładu rodzice bardzo kochają swoje dziecko, zawsze są "przy”, zawsze towarzyszą, nawet, gdy ich nie ma fizycznie "przy”. Wkrada się tu odległość jako wymiar miłości. Ten dystans może być dystansem aż po nieobecność w samej śmierci: oddanie życia „dla”, w nieobecności tego „dla" kogo ktoś umiera z miłości. Będąc najdalej, jest jednak najbliżej, jest to bowiem obecność miłości, która nie ma przestrzeni ani czasu.

Marie-Dominique Philippe jako znawca myśli św. Tomasza z Akwinu powie, że tę rzeczywistość doświadczaną jako niemożliwość oddania przez człowieka wszystkiego w miłości, a taki jest przecież wymóg miłości (być wszystkim we wszystkim dla drugiego), widzi w fakcie niemożliwości zlania w jedno bytu ludzkiego i miłości. To jedynie w Bogu byt i miłość stanowią jedno. Człowiek natomiast istnieje, zanim pokocha ${ }^{49}$, byt/bycie człowieka wyprzedza miłość. Dlatego też miłość, nawet jeżeli jest ona bardzo silna, pojawia się zawsze niejako na drugim miejscu, a to oznacza, iż po to, aby miłować "do końca", trzeba zespolić byt i miłość w jedno, to możliwe jest tylko dla Boga i w Bogu. Człowiek musi zaś umrzeć. Jezus na krzyżu wypełnia tę prawdę, przezwyciężając zaszczepioną w człowieku niemożliwość bycia , jak Bóg jednocześnie" bytem i miłością. Jedynie człowiek w Chrystusie, upodabniając się do Niego, przezwycięża swój egoizm bycia najpierw sobą i dla siebie, nawet w istnieniu, aby w Chrystusie być całkowicie byciem i miłością, być „w końcu” i „do końca” na obraz i podobieństwo Boże.

W ludzkiej miłości, która żyje dla drugiego, która oddaje życie „dla”, poznaje się ten fakt niejako "po omacku”, "po części”, dopiero będąc w miłości Bożej, "twarzą w twarz" wobec Miłości, ujrzy się całą prawdę. Z tej strony pozostaje jedynie i aż zwierciadło tej miłości, tajemnica i nauka krzyża, którą przyjmuje się wiarą: doświadczeniem wydarzenia, że miłość musi być ukrzyżowana, musi być „dla" i to cała, aby została całkowicie oczyszczona z siebie,

${ }^{48}$ E. Stein, Świattość w ciemności, t. I, przekł. s. Immakulata J. Adamska OCD, Kraków 1977, s. 250.

${ }^{49}$ Por. M.-D. Philippe OP, O miłości, Wydawnictwo „M”, Kraków 1995, s. 127-128. 
z własnego egoizmu i pychy. "Jeżeli ziarno nie obumrze zostaje samo", aby wydać nowy kłos miłości, trzeba wpaść w "glebę” krzyża, stać się całkowicie „dla", jak Chrystus.

Czy jest to możliwe dla człowieka, który się lęka śmierci? Odpowiedź znajdujemy w Liście św. Jana: „W miłości nie ma lęku [...], kto się lęka, nie wydoskonalił się w miłości (1 J 4, 18). Moje umieranie z Chrystusem musi być umieraniem w naśladowaniu Chrystusa, Jego męki, Jego służby dla drugiego człowieka, po śmierć swoją i całe własne wyniszczenie.

\section{PERCHÉ NON VENGA RESA VANA LA CROCE DI CRISTO (1 COR 1, 17). IL COMPRENDERE DEL MISTERO DELLA MORTE E DELLA PASSIONE DI GESÙ ALLA LUCE DEGLI ALCUNI ELEMENTI DELLA CRISTIANOLOGIA MORALE DI SAN TOMMASO D'AQUINO}

\section{RIASSUNTO}

L'articolo si impegna di capire fino in fondo il mistero della morte e della passione di Cristo basandosi sull'insegnamento di San Tammaso d'Aquino ripreso soprattutto dalla Summa Theologiae (III, qq. 47-50) e dal suo Commento alla Prima Lettera ai Corinzi, qui 1 Cor 1, 17-25. Cirsto offre al cristino il mandato di predicare e di vivere non un discorso sapiente, cioè la sapienza mondana, che rende solamente verbosi, ma l'insegnamento della fede operata per mezzo della croce di Cristo. Se la dottrina della fede viene presentata mediante un discorso sapiente e solamente umano, potrebbe essere svuotata dal suo vero contenuto, perciò la ragione umana deve entrare nella logica di Dio. Ciò non significa di perdere la ragione, ma il discernimento tra le cose mondane e le cose divine: la sapienza di Dio insegna la vera prudenza. San Tommaso d'Aquino segue qui le orme di San Paolo: Dio ha deciso di salvare il mondo mediante la follia della croce (cfr. 1 Cor 1, 23). Quando si annuncia agli uomini il vangelo della salvezza, si può quindi lasciare da aprte tutto ciò che deriva dalla sapienza umana: la follia della croce non tollera mistificazioni.

La sapienza cristiana non è in tal senso in primo luogo la regola morale, ma rivelazione del mistero di Dio in Cristo stesso. Tuttavia l'aspetto morale della sapienza della croce non è eliminato, ma si basa sull'esemplarismo ontico. Alla luce della rivelazione di Cristo, sapienza di Dio, tutte le regole di condotta morali, aquistano soltano nella persona di Gesù Cristo la pienezza del suo significato. Ciò che concerne la vita cristiana do ogni giorno, in cui bisogna imitare la veritŕ della croce, implica una perfetta rettitudine morale. L'uomo peccatore deve lasciarsi crocifiggere con la sua sapienza orgogliosa, se vuole rinascere in Cristo. Se lo fa, tutto il suo sforzo umano assumerà un senso nuovo, perché si effettuerà ciò che qui viene chiamato "cristianologia morale": divenatre "come" Cristo, "conformarsi" a Lui, senza lascire alcuno spazio per se stessi ed il suo egoismo. 
Qui il cristiano pone la sua fiducia nella forza di Cristo crocifisso, altrimenti si mostrerebbe nemico di croce, e la sua opera salvifica venisse resa vana. Nella vita cristiano ha crocifisso ciò che è vecchio in lui, cosicché à pienamente liberato dal peccato. Il suo giudizio è trasformato dalla sapienza della croce. Mediante questa sapienza egli, sull'esempio di Gesù, diventerà capace di essere nuovo: egli contempla il modello di Cristo, e diviene simile a Lui, anzi come Lui. Christianus dicitur qui Christi est (S. Th., II-II, q. 124, a. 5). 